\title{
First Record of The Urbicola Soft Scale, Pulvinaria urbicola Cockerell, 1893 (Hemiptera: Coccidae) in Egypt
}

\author{
Soad I. Abdel-Razak ${ }^{1}$
}

\begin{abstract}
Pulvinaria urbicola Cockerell, 1893, is recorded from Egypt for the first time in Alexandria infesting Cordia sp. (Boraginaceae), Psidium guajava (Myrtaceae) and Sanchezia speciosa L. (Acanthaceae). Because this species has not been recorded before from Egypt, some characteristics of the adult female are given here to help in future identification in Egypt.
\end{abstract}

Keywords: Coccidae, Hemiptera, Egypt, Pulvinaria urbicola.

\section{INTRODUCTION}

T In Egypt, the genus Pulvinaria Targioni Tozzetti, 1866, is represented by four species, i.e. $P$. chrysanthemi Hall, P. floccifera (Westwood), P. psidii Maskell and $P$. tenuivalvata (Newstead) (Mohammad and Ghabbour, 2008). P. urbicola Cockerell, was first described by Cockerell, (1893), from specimens collected in Kingston, Jamaica, on Capsicum sp (Solanaceae). It has long been suspected that $P$. grabhami Cockerell, described by Cockerell (1903) from Madeira, and known throughout much of Africa, south of the Sahara, might be identical to P. urbicola, it is now clear that both species are identical (Williams, 2007). Furthermore, as suspected by Qin and Gullan (1992), Pulvinaria peninsularis Ferris, described from Lower California and Mexico, by Ferris (1921), was also identical to $P$. urbicola and this was confirmed by Williams (2007). Pulvinaria urbicola is now common in many tropical and temperate areas and has a wide host range of about 86 plant species in 42 plant families (Ben-Dov et al., 2012). By examining the collected specimens, it was found that they are not any of the recorded species in Egypt, therefore the aim of this study is to record this soft scale as new to the Egyptian insect fauna and give the important taxonomical characters distinguish this species from its allies.

\section{MATERIALS AND METHODS}

8 우, collected from King Fouad Greenhouse, ElMontazah garden, Alexandria, Egypt, II. 2009, host: Sanchezia speciosa. S. I. Abdel-Razak coll.; 3 우우
Experimental Farm of Agricultural Research center, Alex. Egypt, XII. 2008, host: Cordia sp. S. I. AbdelRazak coll.; 2 우우 Experimental Farm of Agricultural Research center, Alex. Egypt, VII. 2009, host: Psidum guajava S. I. Abdel-Razak coll. 3 q 9 MNHN no. 10126.1-3 from Guadeloupe on Coccoloba uvifera.

A severe attack of $P$. urbicola was observed on the leaves of Sanchezia speciosa in King Fouad greenhouse in Alexandria governorate, Elmontazah garden; Cordia sp., and Psidium guajava in the Experimental farm of the Agricultural Research Centre, Alexandria.

\section{Comments:}

The species under study which was identified as $P$. urbicola (Fig. 1) resembles the Egyptian species $P$. chrysanthemi and P. floccifera in its general appearance. All are oval; slightly convex light or dark yellowish green. Ovisac elongate, straight or curved ribbed longitudinally about $4-9 \mathrm{~mm}$. However, it differs from both in possessing dermal areolations on the submarginal area of the dorsum and a few ventral tubular ducts in the marginal area of the head. Also in $P$. urbicola, the anal plates each with 4 apical setae and 3 subapical setae, but in $P$. chrysanthemi there are 4 apical setae and 4 subapical setae, and in P. floccifera, there are 4 apical setae and 2 subapical setae. Also, dorsal submarginal tubercules in both $P$. urbicola and $P$. chrysanthemi are absent but they are present in $P$. floccifera. According to Williams and Watson (1990), this species is variable morphologically and several forms are known. The specimens collected from Egypt have a well-developed articulatory sclerosis between the tibia and tarsus, thus being similar to the specimens described by Tanaka et al. (2006) (Fig. 1) from Japan and the series and specimens described by Williams and Watson (1990) from Papua New Guinea, Tuvalu, Cook Islands, New Caledonia, Kiribati and Irian Jaya. But differs from the other specimens described from Papua New Guinea, Kiribati, Solomon Islands, Western Samoa, Vanuatu, Fiji, and Tuvalu, which have a week articulatory sclerosis between the tibia and tarsus, and from the specimens described by Qin and Gullan (1992)

\footnotetext{
${ }^{1}$ Muséum national d'Histoire naturelle, Entomologie,

UMR 7205 MNHN-CNRS, 45, rue Buffon- Paris 75005, France.

Current address: Scale insects and Mealybugs Department,

Plant Protection Research Institute (PPRI), Agricultural

Research Center (ARC),

Sabahia, Baccous, P.O Box 21616, Alexandria, Egypt.

Corresponding Email: soadramadan@ hotmail.com

Received September 02, 2012, Accepted September30, 2012
} 


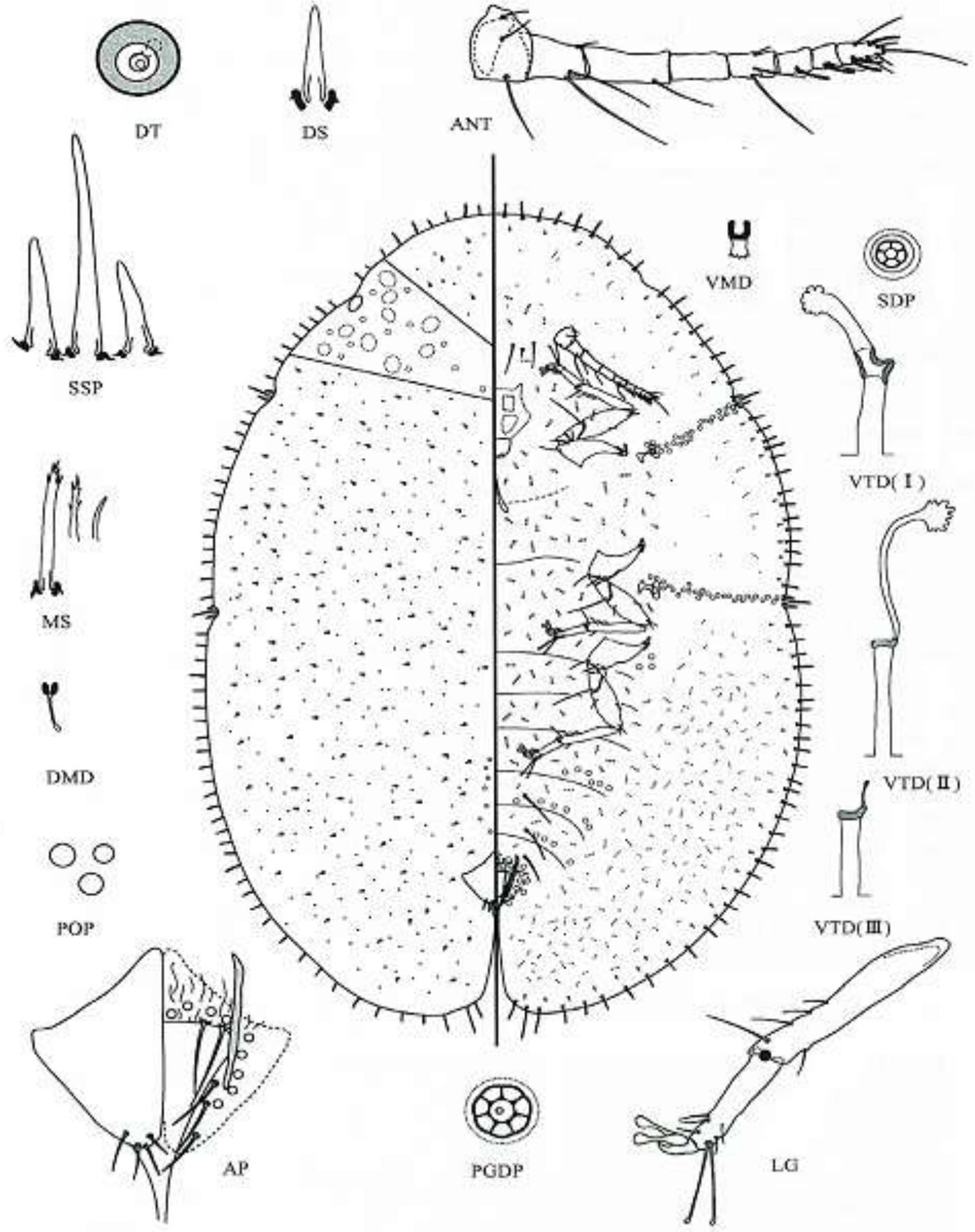

Pulvinaria urbicola, adult female - ANT. Antenna; AP, anal plates; DMD, dorsal microduct; DS, dorsal seta; DT, dorsal tubercle; LG, leg; MS, marginal setae; PGDP, pregenital disc pore; POP, preopercular pores; SDP, spiracular dise pore; SSP, stigmatic spines; VMD, ventral microduct; VTD, ventral tubular ducts of Type I-III.

Fig. 1. Adult female P. urbicola morphological carractrastic after (Tanaka, H., H. Amano and T. Uesato, 2006) 
from Australia, which lack ventral tubular ducts on the head. Also they stated that the absence of submarginal tubercles in Australian specimens distinguishes $P$. urbicola from $P$. decorata, $P$. floccifera, $P$. polygonata and $P$. psidii.

\section{ACKNOWLEDGEMENTS}

Appreciation is extended to Gillian W. Watson, California Department of Food and Agriculture, Sacramento, California, U.S.A., for identifying the specimens of Pulvinaria urbicola in 2009, and to Thierry Bourgoin (Muséum national d'Histoire naturelle, Paris), who allowed me to work at the Entomology Department. I thank Danièle Matile-Ferrero at the same museum for her guidance and support. I thank Jon Martin, Natural History Museum, London, for sending me the type of Pulvinaria chrysanthemi. Also, I thank Douglas Williams, at the same museum, for his comments, discussions and review, which improved significantly the manuscript. This work was supported by a MNHN grant for visiting scientist on 2011.

\section{REFERENCES}

Ben-Dov, Y., D.R. Miller, \& G.A.P. Gibson (2012). Scale Net: a database of the scale insects of the world, Catalogue Query Results, Pulvinaria urbicola Cockerell. http://www.sel.barc.usda.gov/catalogs/coccidae/Pulvinaria urbicola.htm. Accessed 20 June, 2012.
Cockerell, T.D.A., 1893. X. Two new species of Pulvinaria from Jamaica. Trans. Entomol. Soc. London, 41: 159-163.

Cockerell, T.D.A., 1903. A new coccid from Madeira, allied to Coccus tuberculatus Bouche. Entomologist, 36: 261262.

Ferris, G.F. 1921. Report upon a collection of Coccidae from Lower California. Stanford University Publications, Biological Sciences. Palo Alto 1: 61-132.

Mohammad, Z.K. and M.W. Ghabbour, 2008. Updating list of super family Coccoidea (Hemiptera) as known to exist in Egypt. J. Egypt. German Soc. Zool., 56E: 147-162.

Qin, T.K. and P.J. Gullan, 1992. A revision of the Australian pulvinariine soft scales (Insecta: Hemiptera: Coccoidea). J. Nat. History, 26: 103-164.

Tanaka, H., H. Amano and T. Uesato, 2006. A new record of Pulvinaria urbicola Cockerell, 1893 (Hemiptera, Coccidae) from Japan. Jpn. J. Syst. Entomol., 12(2): 177181.

Williams, D.J. and G.W. Watson, 1990. The Scale Insects of the Tropical South Pacific Region. Part 3: The Soft Scales (Coccidae) and Other Families. CAB International Institute of Entomology, London, UK., Pages: 267.

Williams, D.J., 2007. The soft scale insect Pulvinaria urbicola Cockerell (Hem., Coccoidea, Coccidae) and its synonyms. Entomol. Monthly Mag., 143: 91-96.

\section{الملخص العربي}

تسجيل لاول مرة للحشره القشريه الرخوة Pulvinaria urbicola ( رتبه نصفيه الاجنحه:

$$
\begin{aligned}
& \text { فوق عائله الحشرات القشريه) في مصر } \\
& \text { سعاد ابراهيم عبدالززاق } \\
& \text { ولأن هذه الحشرة لم تسجل ولم تدرس من قبل في مصر،لذلك تم } \\
& \text { تم ف ف هذا البحث تسجيل الحشره القشريه الرخوة } \\
& \text { توضيح بعض الصفات التقسيميه لأناث هذه الحشره والتى تميزها عن } \\
& \text { لاول مره في مصر Pulvinaria urbicola (حشره المخيط الرخوة) } \\
& \text { الانواع المعروفه في مصر للمساعده في التعريف المستقبلى. } \\
& \text { والتى تنتمى الى رتبة نصفية الاجنحه:فوق عائلة الحشرات القشريه } \\
& \text { وذلك بمحافظه الاسكندريه.حيث اوضحت الدراسه تواجدها على } \\
& \text { ثلاث عوائل مختلفه وهم اشجار المخيط والجوافه ونبات السنكازيا. }
\end{aligned}
$$

